\title{
PENGARUH PENDEKATAN OPEN-ENDED UNTUK MENINGKATKAN KEMAMPUAN BERPIKIR KREATIF SISWA PADA MATA PELAJARAN FISIKA BERBASIS PERANGKAT LUNAK MODELLUS
}

\author{
Ayu Lusiyana1, Saifur Rohim², dan Fatkhur Rohman ${ }^{3}$ \\ 1,3 STKIP Nurul Huda Sukaraja \\ Sukaraja, OKU Timur, Sumatera Selatan \\ ${ }^{2}$ MA Nurul Huda Sukaraja \\ Sukaraja, OKU Timur, Sumatera Selatan \\ E-mail: ${ }^{1}$ ayu.lusiyana@live.com, ${ }^{2}$ rohim_saifur@yahoo.com, ${ }^{3}$ fatkhur@stkipnurulhuda.ac.id
}

\begin{abstract}
Abstrak
Penelitian ini bertujuan untuk mengetahui pengaruh diberikannya pendekatan open-ended terhadap kemampuan siswa berpikir kreatif pada mata pelajaran fisika yang menggunakan perangkat lunak Modellus dalam pembelajaran. Setelah dilakukan penelitian quasi experiment didapat hasil penelitian: (1) pendekatan open-ended berpengaruh terhadap peningkatan kemampuan berpikir kreatif siswa yang dapat dilihat dari peningkatan hasil belajar dari aspek afektif dan kognitif yang signifikan antara pretest dengan posttest pada kelas eksperimen, dan peningkatan yang tidak begitu besar pada kelas kontrol. (2) Uji statistik dengan N-Gain memperlihatkan dari 25 siswa, untuk kategori sangat tinggi terdapat 4 siswa pada kelas eksperimen, namun tidak ada satu siswapun pada kelas kontrol, untuk kategori sedang terdapat 12 siswa pada kelas eksperimen dan 7 siswa pada kelas kontrol, serta untuk kategori sangat rendah tidak ada satu siswapun di kelas eksperimen dan 3 siswa pada kelas kontrol (3) Uji statistik dengan uji $t$ dua pihak menghasilkan thitung lebih besar dari tabel $(4,723>2,011)$, dan - thitung lebih kecil dari -tabel $(-, 723<-2,011)$.
\end{abstract}

Kata kunci: Open-Ended, Berpikir Kreatif, Perangkat Lunak Modellus.

\section{PENDAHULUAN}

Fisika memiliki peran yang strategis dalam pengembangan dan peningkatan kemajuan ilmu pengetahuan dan teknologi. Untuk memahami mata pelajaran Fisika dibutuhkan penguasaan dan pemahaman konsep-konsep yang mendasar, karena penguasaan dan pemahaman konsep yang mendasar dapat membantu siswa memiliki kemampuan berpikir kreatif. Selain itu, dengan kemampuan penguasaan dan pemahaman tersebut, diharapkan siswa mampu menggunakannya untuk membangkitkan ide baru dan menarik, menganalisis sebuah permasalahan, mengevaluasi, dan mengkonfirmasi, sehingga mendapatkan siswa dapat berpikir kreatif dan dapat menemukan solusi dari permasalahan yang dihadapi serta dapat dipertanggung-jawabkan secara teori dan ilmiah (Ormrod, 2009). Santrock (2008) mempertegas bahwa kemampuan berpikir kreatif yang didapatkan dari akumulasi kemampuan dan pemahaman yang didapat dari pembelajaran dapat memudahkan siswa dalam pencapaian kompetensi pembelajaran sesuai dengan tujuan pendidikan.

Pengembangan kemampuan berpikir kreatif siswa dalam pembelajaran sangat penting, karena dengan kemampuan berpikir yang baik siswa mampu untuk menghubungkan dan melakukan sesuatu dengan segala pengetahuan yang telah dipelajari, serta menggunakan pengetahuan tersebut dalam situasi yang lain. Akan tetapi dalam praktiknya, siswa selalu mengalami kesulitan dalam menemukan solusi atau informasi untuk menyelesaikan permasalahan yang dihadapinya. Sulitnya materi pada mata pelajaran Fisika menjadi alasan yang utama bagi siswa, hal tersebut sejalan dengan data hasil wawancara dan studi awal penelitian di 
Madrasah Aliyah Nurul Huda Sukaraja kelas X. Dari 35 siswa, 16 siswa menyatakan bahwa Fisika itu mata pelajaran yang sulit, 10 siswa menyatakan cukip sulit atau sedang, dan 9 siswa menyatakan materi fisika ada yang sulit, sedang dan mudah. Namun berdasarkan data nilai ujian tengah semester hanya $43 \%$ atau 15 siswa yang mendapatkan nilai tuntas sesuai dengan KKM (Kriteria Ketuntasan Minimal) yang ditetapkan oleh sekolah. Dari hasil tersebut, rendahnya kemampuan berpikir kreatif siswa dalam belajar menjadi diagnosa utama timbulnya masalah dari kesulitan siswa terhadap mata pelajaran Fisika. Hal ini terbukti dari respon siswa yang terdokumentasikan dalam kuesioner penilaian 1) rasa ingin tahu siswa $37 \%$, 2) merasa tertantang dengan kemajemukan $36 \%$, 3) sifat berani mengambil resiko $34 \%$ dan 4) sifat menghargai $35 \%$. Dari nilai-nilai tersebut, secara umum kemampuan berpikir kreatif siswa sangat kurang.

Berdasarkan data tersebut, Peneliti mengkaji dan mengevaluasi bahwa terdapat beberapa permasalahan dalam proses pembelajaran yang ingin diteliti dalam penelitian ini yaitu: (1) Siswa kurang memiliki kemampuan berpikir kreatif karena proses pembelajaran yang berlangsung sebelumnya tidak memfasilitasi siswa untuk membuka cakrawala kemampuan berpikir secara kreatif siswa yang sebenarnya sudah ada di diri siswa, (2) Guru tidak memberi stimulus atau rangsangan-rangsangan yang membuat siswa menggali kemampuan berpikir kreatifnya, (3) Desain pembelajaran yang digunakan sebelumnya hanya berupa penyampaian informasi dari guru ke siswa, sehingga siswa hanya bersifat menerima, tanpa perlu menelaah informasi pengetahuan baru yang didapat.

Untuk meningkatkan kemampuan berpikir kreatif siswa terutama dalam pembelajaran Fisika, penulis berpendapat bahwa harus ada perubahan mendasar dari proses pembelajaran yang digunakan. Jika sebelumnya pembelajaran bersifat teacher center, maka lebih baik diubah menjadi student center. Menurut Morris (2006), siswa yang memiliki kreativitas cenderung menyukai pertanyaan dan tantangan, membuat koneksi antar suatu keadaan dengan keadaan lain, mengeksplorasi ide, dan kritis. Karakteristik ini diharapkan dapat muncul dan berkembang dengan suatu pendekatan yang disebut Openended. Pembelajaran dengan pendekatan open-ended adalah pembelajaran dengan memberi pertanyaan yang "incomplete", lalu siswa menjawab dengan beraneka jawaban benar terhadap permasalahan yang ditanyakan untuk menemukan hal atau pengetahuan baru di dalam proses pembelajaran. Kegiatan ini dapat terlaksana dengan adanya kombinasi antara pengetahuan awal siswa, keterampilan, dan pola pikir siswa itu sendiri yang berasal dari pelajaran sebelumnya (Shimada, 1997).

Sejalan dengan tujuan penggunaan pendekatan open-ended, untuk merangsang peningkatan kemampuan berpikir siswa perlu digunakan media pembelajaran yang mutakhir, interaktif, dan membuat siswa tertarik. Penulis memilih menggunakan perangkat lunak Modellus. Modellus dirasa cocok untuk mendampingi proses pembelajaran Fisika dengan keunggulannya yaitu mampu menelusuri fenomena fisika dan menemukan hubungan matematis yang membangun fenomena fisika tersebut (Teodoro, 2002).

Dari uraian identifikasi masalah tersebut maka peneliti melakukan penelitian berjudul "Pengaruh Pendekatan Open-Ended untuk Meningkatkan Kemampuan Berpikir Kreatif Siswa pada Mata Pelajaran Fisika Berbasis Perangkat Lunak Modellus".

\section{METODE/EKSPERIMEN}

\section{Deskripsi Subjek dan Waktu Penelitian}

Penelitian ini dilakukan di Madrasah Aliyah Nurul Huda dengan populasi seluruh siswa kelas $X_{1}, X_{2}, X_{3}, X_{4}$, dan diambil sampel penelitian $X_{1}$ dan $X_{3}$ secara pengundian kelas. Penelitian ini akan dilaksanakan pada bulan November sampai dengan Desember 2016.

\section{Variabel dan Disain penelitian}

Variabel dalam penelitian ini adalah 1) Variabel bebas (Pendekatan open-ended) dan 2) Variabel terikat (Kemampuan berpikir kreatif siswa pada materi Dinamika Gerak Lurus 
dalam mata pelajaran Fisika. Sedangkan desain yang digunakan dalam penelitian ini adalah The Non Equivalent Control Group dari jenis penelitian Quasi Experiment. Digunakan jenis penelitian Quasi Experiment karena dalam penelitian yang dilakukan banyak faktorfaktor yang tidak bisa dikendalikan oleh peneliti (Yusuf, 2005). Desain penelitian dapat dilihat pada tabel berikut:

Tabel 1. Desain Penlitian

\begin{tabular}{llll}
\hline \multicolumn{1}{c}{ Kelas } & pretest & perlakuan & postest \\
\hline $\begin{array}{l}\text { Kelas } \\
\text { eksperimen }\end{array}$ & $\mathrm{O}_{1}$ & Open-ended & $\mathrm{O}_{2}$ \\
$\begin{array}{l}\text { Kelas } \\
\text { control }\end{array}$ & $\mathrm{O}_{3}$ & Konvensional & $\mathrm{O}_{4}$ \\
\hline
\end{tabular}

\section{Instrumen penelitian}

Instrumen pengumpulan data dalam penelitian ini peneliti menggunakan dua jenis instrumen yaitu 1) Kuesioner untuk mengukur sikap dalam berpikir kreatif, dan 2) tes uraian untuk mengukur kemampuan kognitif siswa dalam berfikir kreatif.

1. Lembar Kuesioner

Lembar kuesioner dalam penelitian ini digunakan untuk mengukur kemampuan berpikir kreatif yang berkaitan dengan sikap siswa (aspek afektif). Indikator yang akan diukur dalam kuesioner (1) rasa ingin tahu, (2) merasa tertantang oleh kemajemukan, (3) sifat berani mengambil resiko, dan (4) sifat menghargai. Penentuan skala pada kuesioner menggunakan skala Likert $(5,4,3,2,1)$. Adapun kisi-kisi kuesioner yang akan digunakan dapat dilihat pada Tabel 2.

Tabel 2. Kisi-kisi kuesioner penilaian

\begin{tabular}{ll}
\hline \multicolumn{1}{c}{ Aspek-aspek } & \multicolumn{1}{c}{ Indikator } \\
\hline Rasa ingin tahu & $\begin{array}{l}\text { Antusias pada setiap proses } \\
\text { pembelajaran } \\
\text { Antusias mencarai jawaban } \\
\text { dari permasalahan yang telah } \\
\text { diajukan. }\end{array}$ \\
Merasa & Merasa tertantang oleh soal- \\
tertantang oleh & soal yang bersifat kompleks \\
kemajemukan & Mencari penyelesaian tanpa \\
& $\begin{array}{l}\text { bantuan orang lain dan } \\
\text { berusaha terus menerus agar }\end{array}$ \\
bifat & berhasil \\
mengambil & Berani mempertahakan \\
resiko & $\begin{array}{l}\text { gagasan atau pendapatnya } \\
\text { walaupun mendapat } \\
\text { tantangan atau kritik } \\
\text { Bersedia mengakui } \\
\text { kesalahan-kesalahannya } \\
\text { Berani mengajukan }\end{array}$
\end{tabular}

\begin{tabular}{ll}
\hline Aspek-aspek & \multicolumn{1}{c}{ Indikator } \\
& pertanyaan atau \\
& mengemukakan masalah \\
& yang tidak dikemukakan \\
& orang lain \\
& Tidak mudah dipengaruhi \\
& orang lain, dan berani \\
& mencoba hal-hal baru. \\
& Mempertimbangkan setiap \\
Sifat & masukan dari orang lain \\
menghargai & untuk penyempurnaan \\
& penyelesaian tugas. \\
& Menghargai kebebasan \\
& terhadap pendapat tetapi tahu \\
& bahwa kebebasan \\
& berpendapat menuntut \\
& tanggung jawab \\
& Menghargai kesempatan- \\
& kesempatan yang diberikan \\
& terhadap diri sendiri atau \\
& orang lain \\
\hline
\end{tabular}

\section{Tes uraian}

Tes uraian dalam penelitian ini digunakan untuk mengukur tingkat kemampuan kreativitas siswa pada aspek kognitif (pengetahuan). Aspek-aspek penilaian pada tes uraian mengacu (1) kemampuan berpikir lancar (fluency), (2) kemampuan berpikir luwes/fleksibel (flexibility) (3) kemampuan berpikir orisinal (originality), dan kemampuan memperinci (elaboration). Adapun indikator-indikator pada aspek penilaian kemampuan kreatif siswa dalam tes uraian dapat dilihat pada tabel 3 .

Tabel 3. Indikator-indikator pada aspek penilaian kemampuan kreatif siswa

\begin{tabular}{ll}
\hline \multicolumn{1}{c}{ Aspek-aspek } & \multicolumn{1}{c}{ Indikator } \\
\hline $\begin{array}{l}\text { Kemampuan } \\
\text { berpikir lancar } \\
\text { (fluency) }\end{array}$ & $\begin{array}{l}\text { Kemampuan mengemukakan atau } \\
\text { menuliskan ide-ide yang serupa } \\
\text { untuk memecahkan suatu masalah } \\
\text { yang disajikan dalam tes uraian }\end{array}$ \\
Kemampuan & $\begin{array}{l}\text { Kemampuan menghasilkan } \\
\text { berbagai macam ide guna }\end{array}$ \\
berpikir & memecahkan suatu masalah \\
luwes/fleksibel & dalam tes uraian secara \\
(flexibility) & beragam/bervariasi. \\
Kemampuan & Kemampuan memberikan respon \\
berpikir orisinal & dan jawaban yang benar terhadap \\
(originality) & permasalahan dengan sajian \\
Kemampuan & sendiri yang tidak biasa. \\
memperinci & memampuan mengembangkan atau \\
(elaboration) & terhadap permasalahan yang \\
& diberikan dalam tes uraian
\end{tabular}




\section{Teknik analisis data}

Teknik analisis data penelitian dalam penelitian ini dilakukan dengan cara menghitung nilai rata-rata (mean), standar deviasi, dan menentukan kategori tinggi, sedang dan rendah pada data penelitian sebagai hasil dari kemampuan berpikir kreatif siswa pada mata pelajaran Fisika.

1. Nilai rata-rata (mean)

$$
\bar{X}=\frac{\sum_{i=1}^{n} f_{i} x_{i}}{\sum_{i=1}^{n} f_{i}} \text { (Sugiyono, 2012) }
$$

2. Standar deviasi

$$
S D=\sqrt{\frac{n \sum_{i=1}^{n} f_{i} x_{i}^{2}-\left(\sum_{i=1}^{n} f_{i} x_{i}\right)^{2}}{n(n-1)}}
$$

(Sugiyono, 2012)

3. Kategori tinggi sedang dan rendah kemampuan berpikir kreatif siswa dalam Arikunto (2015) dapat diklasfikasikan berdasarkan Tabel 4.

Tabel 4. Klasifikasi pembagian kategori tinggi sedang dan rendah

\begin{tabular}{lll}
\hline Klasifikasi & Nilai & Ketentuan klasifikasi nilai \\
\hline $\begin{array}{l}\text { Kategori } \\
\text { tinggi }\end{array}$ & $X_{\mathrm{t}}$ & $X_{t} \geq \bar{X}+S D$ \\
$\begin{array}{l}\text { Kategori } \\
\text { sedang }\end{array}$ & $X_{\mathrm{s}}$ & $\bar{X}+S D>X_{S}>\bar{X}-S D$ \\
$\begin{array}{l}\text { Kategori } \\
\text { rendah }\end{array}$ & $X_{\mathrm{r}}$ & $X \leq \bar{X}-S D$ \\
\hline
\end{tabular}

\section{Uji gain faktor (N-gain)}

Gain adalah selisih antara nilai Posttest dan pretest dalam data penelitian. Gain menunjukkan peningkatan pemahaman atau kemampuan berfikir kreatif siswa setelah pembelajaran dilakukan guru. Untuk menghindari hasil kesimpulan bias penelitian, karena pada nilai pretest kedua kelompok penelitian sudah berbeda digunakan uji normalitas Ain (2013). Untuk mencari nilai indeks $\mathrm{N}$-gain menggunakan Persamaan 3.

$$
N-\text { Gain }=\frac{O_{\text {post }}-O_{\text {pre }}}{O_{\text {max }}-O_{\text {pre }}}
$$

Nilai $\mathrm{N}$-gain selanjutnya dikonsultasikan pada tabel 5 kriteria $\mathrm{N}$-gain ternormalisasi berikut:
Tabel 5. Klasifikasi kriteria N-Gain

\begin{tabular}{cc}
\hline Perolehan N-Gain & Kategori \\
\hline $\mathrm{g} \leq 0,20$ & Sangat rendah \\
$0,21-0,40$ & Rendah \\
$0,41-0,60$ & Sedang \\
$0,61-0,80$ & Tinggi \\
$0,81-1,00$ & Sangat tinggi \\
\hline Sumber: Meltzer dalam Hayat (2011)
\end{tabular}

5. Uji hipotesis penelitian

Uji hipotesis penelitian dapat dilakukan dengan menggunakan uji t Yusuf (2015).

$$
t=\frac{\bar{X}_{1}-\bar{X}_{2}}{\sqrt{\left[\frac{\left(n_{1}-1\right) S_{1}^{2}+\left(n_{2}-1\right) S_{2}^{2}}{n_{1}+n_{2}-2}\right]\left[\frac{1}{n 1}+\frac{1}{n 2}\right]}}
$$

Uji hipotesis yang digunakan dalam penelitian ini adalah uji dua pihak sesuai dengan grafik penerimaan/penolakan $\mathrm{H}_{0}$ berikut:

$-t_{\text {tabel }} \leq \pm t_{\text {hitung }} \leq t_{\text {tabel }}$ terima $\mathrm{H}_{0}$ penelitian $-t_{\text {tabel }}> \pm t_{\text {hitung }}>t_{\text {tabel }}$ terima $\mathrm{H}_{\mathrm{a}}$ penelitian

dengan rumusan hipotesis penelitian :

$\mathrm{H}_{\mathrm{a}}$ : Terdapat pengaruh penerapan pendekatan open-ended terhadap peningkatan kemampuan berpikir kreatif siswa pada mata pelajaran Fisika berbasis perangkat lunak Modellus.

$\mathrm{H}_{0}$ : Tidak terdapat pengaruh penerapan pendekatan open-ended terhadap peningkatan kemampuan berpikir kreatif siswa pada mata pelajaran Fisika berbasis perangkat lunak Modellus.

\section{HASIL DAN PEMBAHASAN}

Penelitian ini bertujuan untuk mengetahui pengaruh pendekatan open-ended terhadap peningkatan kemampuan berpikir kreatif siswa pada materi Dinamika Gerak Lurus di dalam pembelajaran Fisika berbasis perangkat lunak Modellus di Madrasah Aliyah Nurul Huda Sukaraja Kecamatan Buay Madang Kabupaten OKU Timur Tahun Pembelajaran 2016/2017. Penelitian dilakukan pada kelas $X_{1}$ yang dipilih sebagai kelas eksperimen dan kelas $X_{3}$ sebagai kelas kontrol dalam penelitian ini. Berikut uraian 
analisis data hasil penelitian.

\section{HASIL \\ Hasil Analisis Data Penelitian Kelas Eksperimen}

Data yang diambil dalam penelitian ini pada kelas eksperimen adalah hasil belajar siswa sebelum (data pretest) dan sesudah (data posttest) diterapkan pembelajaran dengan pendekatan open-ended menggunakan perangkat lunak Modellus. Data tersebut adalah data kemampuan berpikir kreatif berupa sikap (afektif) dan pengetahuan (kognitif) siswa. Hasil pretest kemampuan berpikir kreatif pada kelas eksperimen dapat dilihat pada Gambar 1.

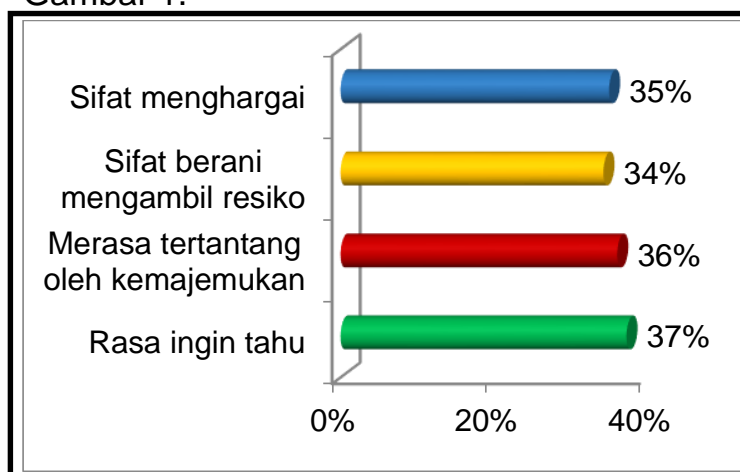

(a)

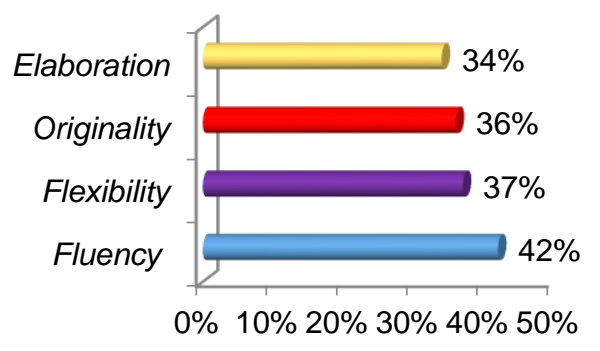

(b)

Gambar 1. Data pretest kemampuan berpikir kreatif siswa (a) aspek afektif (b) aspek kognitif

Setelah mendapatkan data pretest, penulis lalu merancang dan kemudian menjalankan program pembelajaran menggunakan pendekatan open-ended berbasis perangkat lunak Modellus sebanyak empat kali pertemuan tatap muka dengan alokasi waktu 4x135 menit dengan alur kegiatan seperti terlihat pada Gambar 2 berikut.

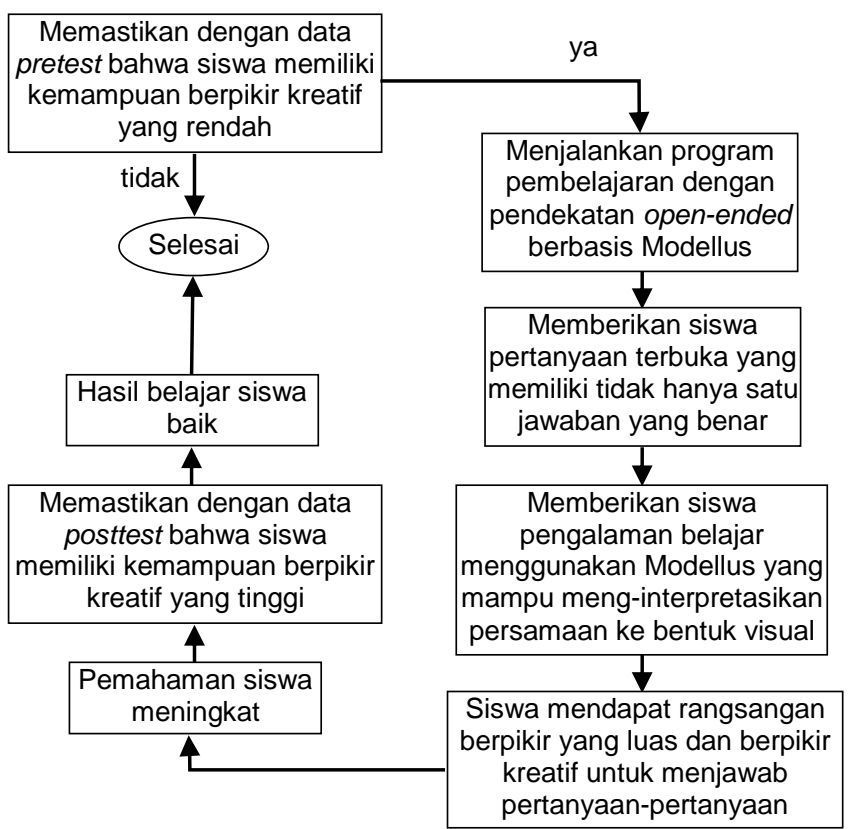

Gambar 2. Diagram alir kegiatan penerapan pendekatan open-ended berbasis perangkat lunak Modellus

Setelah proses pembelajaran dilaksanakan, lalu dilakukan posttest dengan instrument tes yang sama yang diberikan kepada siswa kelas eksperimen saat pretest. Data hasil posttest kemampuan berpikir kreatif pada kelas eksperimen dapat dijelaskan pada Gambar 3.

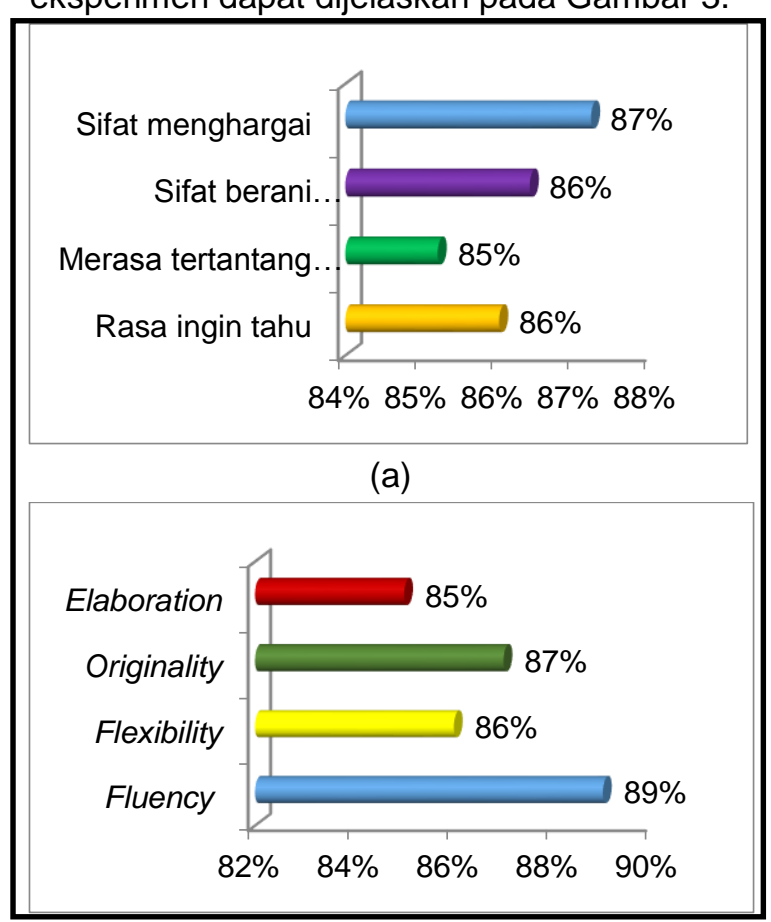

(b)

Gambar 3. Data Posttest kemampuan 
berpikir kreatif siswa (a) aspek afektif (b) aspek kognitif

Adapun data penilaian dapat disajikan dalam Tabel 6.

Tabel 6. Hasil analisis data penelitian kemampuan berpikir kreatif siswa pada kelas eksperimen

\begin{tabular}{llll}
\hline \multicolumn{1}{c}{$\begin{array}{c}\text { Analisis } \\
\text { data }\end{array}$} & $\begin{array}{c}\text { Data } \\
\text { Pretest } \\
\left(\mathrm{O}_{1}\right)\end{array}$ & $\begin{array}{c}\text { Data } \\
\text { Posttest } \\
\left(\mathrm{O}_{2}\right)\end{array}$ & $\begin{array}{c}\text { Data } \\
\text { Gain } \\
\left(\mathrm{O}_{2}-\mathrm{O}_{1}\right)\end{array}$ \\
\hline $\mathrm{X}_{\max }$ & 65 & 90 & 55 \\
$\mathrm{X}_{\min }$ & 30 & 55 & 20 \\
Rata-rata & 46,60 & 78,40 & 31,80 \\
$\mathrm{SD}$ & 10,07 & 9,97 & 11,08 \\
Kategori & 5 siswa & 9 siswa & 6 siswa \\
tinggi & & & \\
Kategori & 15 siswa & 8 siswa & 19 siswa \\
sedang & & & \\
Kategori & 5 siswa & 3 siswa & - \\
Rendah & & & \\
\hline
\end{tabular}

\section{Hasil Analisis Data Penelitian Kelas Kontrol}

Hasil pretest kemampuan berpikir kreatif pada kelas kontrol dapat dilihat pada Gambar 4.

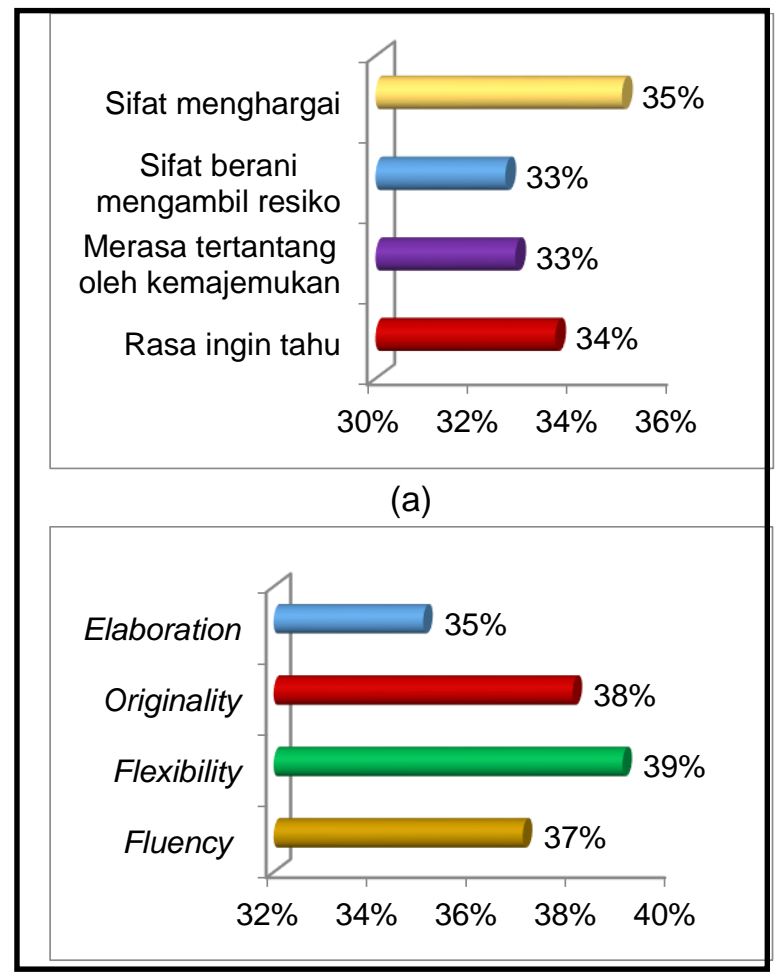

(b)

Gambar 4. Data Pretest kemampuan berpikir kreatif siswa (a) aspek afektif (b) aspek kognitif

Untuk data hasil postest kemampuan berpikir kreatif pada kelas kontrol dapat dijelaskan pada Gambar 5.

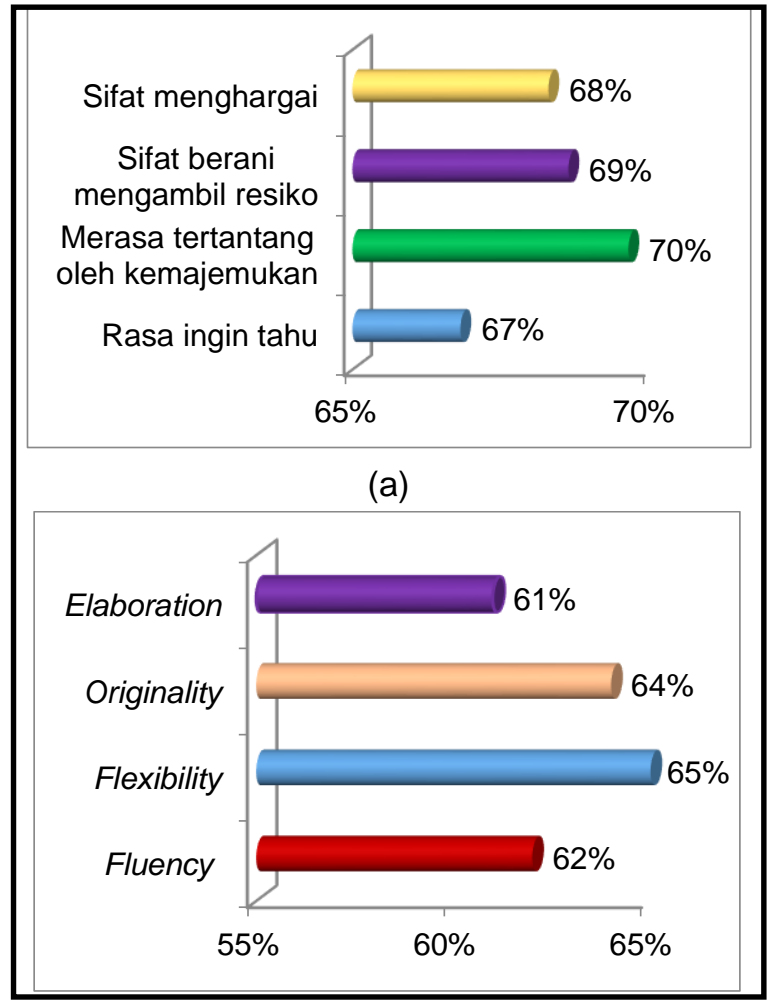

(b)

Gambar 5. Data postest kemampuan berpikir kreatif siswa (a) aspek afektif (b) aspek kognitif

Adapun data penilaian dapat disajikan dalam Tabel 7.

Tabel 7. Hasil analisis data penelitian kemampuan berpikir kreatif siswa pada kelas kontrol

\begin{tabular}{llll}
\hline $\begin{array}{c}\text { Analisis } \\
\text { data }\end{array}$ & $\begin{array}{c}\text { Data } \\
\text { Pretest } \\
\left(\mathrm{O}_{1}\right)\end{array}$ & $\begin{array}{c}\text { Data } \\
\text { Postest } \\
\left(\mathrm{O}_{2}\right)\end{array}$ & $\begin{array}{c}\text { Data } \\
\text { Gain } \\
\left(\mathrm{O}_{2}-\mathrm{O}_{1}\right)\end{array}$ \\
\hline $\mathrm{X}_{\max }$ & 65 & 80 & 45 \\
$\mathrm{X}_{\min }$ & 30 & 45 & 10 \\
$\begin{array}{l}\text { Rata-rata } \\
\mathrm{SD}\end{array}$ & 44,4 & 66 & 21,6 \\
$\begin{array}{l}\text { Kategori } \\
\text { tinggi }\end{array}$ & 9,28 & 8,54 & 10,38 \\
$\begin{array}{l}\text { Kategori } \\
\text { sedang }\end{array}$ & 5 siswa & 0 & 4 siswa \\
$\begin{array}{l}\text { Kategori } \\
\text { Rendah }\end{array}$ & 3 siswa & 19 siswa & 15 siswa \\
\hline
\end{tabular}

Hasil Analisis Uji Efektifitas dan Uji Hipotesis Data Penelitian

Adapun hasil dari uji efektifitas ini dapat dilihat pada Tabel 8. 
Tabel 8. Uji Efektifitas N_Gain

\begin{tabular}{ccc}
\hline Kategori & Kelas & Kelas \\
Perolehan & Eksperimen & Kontrol \\
\cline { 2 - 3 } N-Gain & Jumlah & Jumlah \\
\hline Sangat rendah & 0 siswa & 3 siswa \\
Rendah & 4 siswa & 13 siswa \\
Sedang & 12 siswa & 7 siswa \\
Tinggi & 5 siswa & 2 siswa \\
Sangat tinggi & 4 siswa & 0 siswa \\
\hline
\end{tabular}

Berdasarkan data dari Tabel 8 dapat digambarkan dalam perbandingan grafik antara efektifitas kelas eksperimen dan kelas kontrol pada Gambar 6.

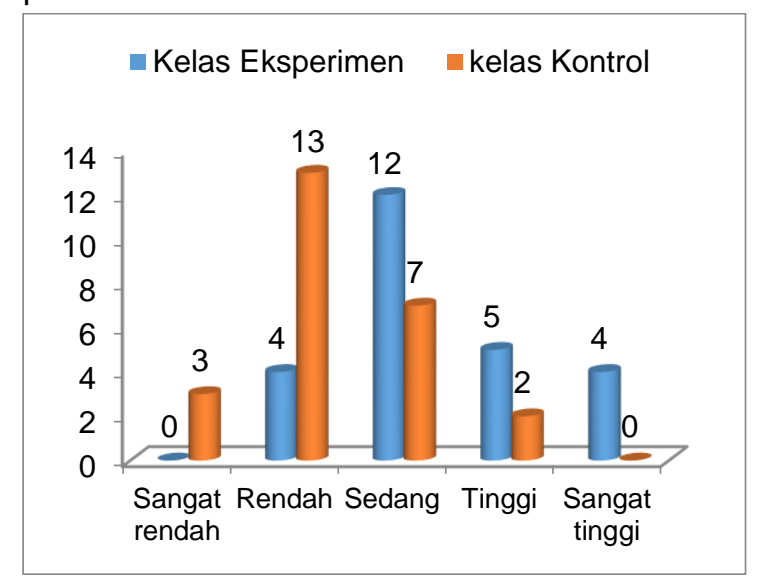

Gambar 6. Grafik Perbandingan Hasil Uji Efektifitas

Hasil analisis uji hipotesis menggunakan uji t dapat dilihat pada Tabel 9.

Tabel 9. Hasil Analisis Uji $\mathrm{t}$

\begin{tabular}{lccc}
\hline $\begin{array}{c}\text { Number } \\
\text { Probability }\end{array}$ & $\begin{array}{c}\text { Number } \\
\text { Deg_freedom }\end{array}$ & tabel & thitung \\
\hline $5 \%$ & 58 & 2,011 & 4,723 \\
\hline
\end{tabular}

Tabel 9 di atas dapat direpresentasikan ke dalam grafik penerimaan dan penolakan Ho seperti Gambar 7.

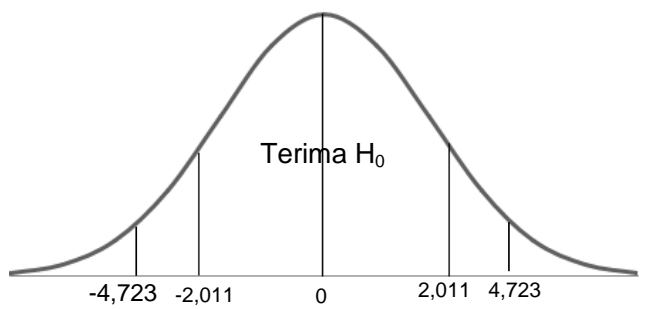

Gambar 7. Grafik penerimaan dan penolakan Ho pada Uji t dua pihak

\section{PEMBAHASAN}

\section{Pembahasan Hasil Analisis Data Penelitian Kelas Eksperimen}

Berdasarkan Gambar 1 dapat dijelaskan bahwa kemampuan awal siswa pada kelas eksperimen untuk aspek berpikir kreatif memiliki persentase yang cukup rendah. Dari Gambar 1a (atas) terlihat bahwa kemampuan berpikir kreatif siswa yang dinilai dari aspek afektif menggunakan kuesioner seluruhnya memiliki persentase sedikit bahkan dibawah $40 \%$. Kategori sifat menghargai, sikap berani mengambil resiko, merasa tertantang oleh kemajemukan, dan rasa ingin tahu belum sepenuhnya dimiliki siswa di awal pembelajaran dalam penelitian ini.

Sejalan dengan hal di atas, pada Gambar $1 b$ (bawah) terlihat bahwa kemampuan berpikir kreatif dari aspek kognitif dalam menjawab soal-soal tes berupa uraian masih juga belum begitu baik. Kriteria berpikir kreatif seperti fluency, flexibility, originality, dan elaboration masih berada pada persentase rerata yang tidak begitu baik. Dari dua data pretest inilah penulis yakin bahwa sangat perlu diadakan upaya peningkatan kemampuan berpikir kreatif siswa dengan cara menggunakan pendekatan open-ended dan berbasis pada perangkat lunak Modellus.

Berdasarkan Gambar 3a (atas) dapat diketahui bahwa kemampuan siswa setelah diberi perlakuan berupa penerapan pendekatan open-ended untuk aspek berpikir kreatif memiliki persentase yang tinggi. Dari Gambar 3a (atas) terlihat bahwa kemampuan berpikir kreatif siswa yang dinilai dari aspek afektif menggunakan kuesioner seluruhnya memiliki persentase di atas $85 \%$. Seluruh aspek mengalami peningkatan dari kondisi awal sebelum penerapan pendekatan open-ended. Kategori sifat menghargai, sikap berani mengambil resiko, merasa tertantang oleh kemajemukan, dan rasa ingin tahu sudah hampir keseluruhan dimiliki siswa di akhir pembelajaran dalam penelitian ini.

Sejalan dengan hal di atas, pada Gambar 3b 
(bawah) terlihat bahwa kemampuan berpikir kreatif dari aspek kognitif dalam menjawab soal-soal tes berupa uraian sudah sangat baik. Kriteria berpikir kreatif seperti fluency, flexibility, originality, dan elaboration masih berada pada persentase rerata yang tinggi di atas $85 \%$.

Selanjutnya data hasil pretest dan posttest pada aspek afektif dan kognitif diinterpretasikan menjadi satu ke dalam bentuk angka sebagai penilaian keseluruan terhadap kemampuan siswa berpikir kreatif dalam pembelajaran Fisika pada materi dinamika gerak lurus. Dari data yang diperlihatkan pada Tabel 6 , dapat diketahui bahwa rata-rata hasil penilaian kemampuan berpikir kreatif siswa aspek afektif dan kognitif mengalami peningkatan yang cukup besar. Hal ini juga dirasakan oleh guru bahwa setelah proses pembelajaran selesai, siswa menjadi lebih terampil dan aktif menggunakan kemampuan berpikir kreatifnya terhadap persoalan Fisika yang diberikan kepadanya. Penalaran dan penjabaran jawaban serta analisis persoalan yang diperlihatkan siswa semakin baik dan mumpuni.

Pada Tabel 6 juga terlihat bahwa jumlah siswa yang berada pada kategori memiliki kemampuan berpikir kreatif tinggi meningkat, dan jumlah siswa yang berada pada kategori berkemampuan berpikir kreatif sedang dan rendah menurun. Hal ini mencerminkan kesuksesan penerapan pendekatan openended dalam pembelajaran Fisika yang mampu mengantarkan lebih banyak siswa berpikir kreatif.

\section{Pembahasan Hasil Analisis Data Penelitian Kelas Kontrol}

Berbeda dengan perlakuan pada kelas eksperimen, dalam penelitian ini data penelitian untuk kelas kontrol yaitu berupa data hasil belajar siswa sebelum (data pretest) dan sesudah (data postest) diterapkan pembelajaran tanpa menggunakan pendekatan open-ended dan perangkat lunak Modellus. Data tersebut adalah data kemampuan berpikir kreatif berupa sikap (afektif) dan pengetahuan (kognitif) siswa.

Berdasarkan Gambar 4 dapat dijelaskan bahwa kemampuan awal siswa pada kelas kontrol untuk aspek berpikir kreatif memiliki persentase yang cukup rendah, sama dengan kemampuan awal siswa pada kelas eksperimen. Dari Gambar 4a (atas) terlihat bahwa kemampuan berpikir kreatif siswa yang dinilai dari aspek afektif menggunakan kuesioner seluruhnya memiliki persentase sedikit bahkan dibawah $40 \%$. Kategori sifat menghargai, sikap berani mengambil resiko, merasa tertantang oleh kemajemukan, dan rasa ingin tahu belum sepenuhnya dimiliki siswa di awal pembelajaran.

Sejalan dengan hal di atas, pada Gambar 4b (bawah) terlihat bahwa kemampuan berpikir kreatif dari aspek kognitif dalam menjawab soal-soal tes berupa uraian masih juga belum begitu baik. Kriteria berpikir kreatif seperti fluency, flexibility, originality, dan elaboration masih berada pada persentase rerata yang tidak begitu baik, di bawah $40 \%$. Namun untuk melihat pengaruh penerapan pendekatan open-ended pada kelas eksperimen, kelas kontrol tidak diterapkan pendekatan openended melainkan menggunakan pembelajaran konvensional.

Berdasarkan Gambar 5a (atas) dapat diketahui bahwa kemampuan siswa setelah proses pembelajaran dilaksanakan memiliki peningkatan persentase. Dari Gambar 5a (atas) terlihat bahwa kemampuan berpikir kreatif siswa yang dinilai dari aspek afektif menggunakan kuesioner seluruhnya memiliki persentase di atas $60 \%$. Seluruh aspek mengalami peningkatan dari kondisi awal. Kategori sifat menghargai, sikap berani mengambil resiko, merasa tertantang oleh kemajemukan, dan rasa ingin tahu sudah hampir keseluruhan dimiliki siswa di akhir pembelajaran dalam penelitian ini. Tidak terjadi kenaikan persentase secara signifikan, dikarenakan pada proses pembelajaran konvensional siswa tidak dirangsang untuk memiliki pola pikir kreatif. Peningkatan ini mungkin terjadi karena siswa sudah memiliki pengetahuan yang cukup setelah pembelajaran.

Sejalan dengan hal di atas, pada Gambar 5b (bawah) terlihat bahwa kemampuan berpikir kreatif dari aspek kognitif dalam menjawab soal-soal tes berupa uraian juga meningkat. 
Kriteria berpikir kreatif seperti fluency, flexibility, originality, dan elaboration masih berada pada persentase rerata yang sedang di atas $60 \%$.

Data hasil pretest dan postest pada aspek afektif dan kognitif diinterpretasikan menjadi satu dalam bentuk angka sebagai penilaian kemampuan siswa berpikir kreatif dalam pembelajaran fisika pada materi dinamika gerak lurus.

Dari Tabel 7 dapat diketahui bahwa meski tanpa penerapan pendekatan open-ended, rata-rata hasil penilaian kemampuan berpikir kreatif siswa aspek afektif dan kognitif juga mengalami peningkatan. Pada Tabel 7 juga terlihat bahwa jumlah siswa yang berada pada kategori memiliki kemampuan berpikir kreatif sedang dan rendah meningkat, dan jumlah siswa yang berada pada kategori berkemampuan berpikir kreatif tinggi menurun.

Perbedaan hasil penilaian kemampuan berpikir kreatif siswa aspek afektif dan kognitif antara kelas eksperimen dan kelas kontrol tidak bisa dijadikan pedoman sepenuhnya untuk menyimpulkan bahwa terdapat peningkatan kemampuan berpikir kreatif Fisika menggunakan pendekatan open-ended. Perlu dilakukan analisis data nilai posttest menggunakan uji statistik melalui uji hipotesis penelitian dan uji efektifitas.

\section{Pembahasan Hasil Analisis Uji Efektifitas dan Uji Hipotesis Data Penelitian}

Sesuai penjabaran sebelumnya bahwa uji efektifitas N-Gain menunjukkan peningkatan kemampuan berfikir kreatif siswa setelah pembelajaran dengan penerapan pendekatan open-ended dengan perangkat lunak Modellus dilaksanakan.

Dari Gambar 6 di atas terlihat jelas bahwa efektifitas pembelajaran dengan menerapkan pendekatan open-ended berbasis perangkat lunak Modellus pada kelas eksperimen lebih baik daripada kelas kontrol. Jumlah siswa yang terkategori sangat tinggi terhitung banyak, dan tidak ada siswa yang terkategori sangat rendah. Lain halnya dengan keadaan di kelas control, jumlah siswa yang terkategori sangat tinggi tidak ada, tetapi ada beberapa siswa yang terkategori sangat rendah. Hal ini mengindikasikan bahwa penerapan pendekatan open-ended dengan perangkat lunak Modellus efektif dilaksanakan untuk meningkatkan kemampuan berpikir kreatif siswa.

Pengujian selanjutnya adalah uji hipotesis untuk mengetahui perbedaan pengaruh diterapkannya pendekatan open-ended dengan perangkat lunak Modellus terhadap kemampuan berpikir kreatif siswa. Dari gambar 7 jelas terlihat bahwa nilai $-t_{\text {tabel }}> \pm t_{\text {hitung }}>$ $t_{\text {tabel, }}$ maka hipotesis alternatif dalam penelitian ini diterima. Artinya memang terdapat pengaruh pendekatan open-ended untuk meningkatkan kemampuan berpikir kreatif siswa pada mata pelajaran fisika berbasis perangkat lunak Modellus.

\section{PENUTUP}

Berdasarkan penelitian yang telah dilakukan tentang penerapan pendekatan open-ended untuk meningkatkan kemampuan berpikir kreatif siswa pada mata pelajaran fisika berbasis perangkat lunak Modellus didapatkan data hasil bahwa pendekatan open-ended berpengaruh terhadap peningkatan kemampuan berpikir kreatif siswa yang dapat dilihat dari peningkatan hasil belajar dari aspek afektif dan kognitif yang signifikan antara pretest dengan posttest pada kelas eksperimen, dan peningkatan yang tidak begitu besar pada kelas kontrol.

Data ini juga didukung dari hasil uji statistik berupa uji efektifitas dan uji hipotesis dengan uji $t$ dua pihak dengan perolehan uji efektifitas dengan N-Gain seperti yang terlihat pada Tabel 8. Sedangkan Uji t dua pihak menghasilkan thitung yang lebih besar dari tabel $(4,723>2,011)$, dan - thitung yang lebih kecil dari -ttabel $(-4,723<-$ 2,011).

\section{UCAPAN TERIMAKASIH}

Terimakasih kami ucapkan kepada Pimpinan Sekolah Tinggi Keguruan dan IImu Pengetahuan Nurul Huda Sukaraja Serta terimakasih kepada Pimpinan Madrasah Aliyah Nurul Huda Sukaraja beserta jajaran staf dan para guru serta siswa yang telah membantu 
peneliti menyediakan arena penelitian dan membantu keterlaksanaan penelitian ini.

\section{DAFTAR PUSTAKA}

Ain, Trise Nurul. (2013). Pemanfaatan Visualisasi Video Percobaan Gravity Current untuk Meningkatkan Pemahaman Konsep Fisika pada Materi Tekanan Hidrostatis. Jurnal Inovasi Pendidikan Fisika. Vol 02 No 02.97 $-102$.

Arikunto, Suharsimi. (2015). Dasar-Dasar Evaluasi Pendidikan. Jakarta: Bumi Aksara.

Arvina Yulindar, Johar Maknun dan Muslim. (2017). Penggunaan Instrumen Tes Fisika Berbasis Open-Ended Question Sebagai Sarana Berpikir Kritis dan Kreatif Siswa SMA. Jurnal Wahana Pendidikan Fisika Vol.2 No.1 ISSN: 2338-1027, 80-85.

Fiki Silvia, Risnita, dan Syaiful. (2015). Pengembangan Rubrik Keterampilan Berpikir Kreatif dalam Memecahkan Masalah Matematika Siswa Kelas VIII SMP Attaufiq Jambi. Edu-Sains Volume 4 No .1, 10-20.

Fitriani. (2014). Upaya Meningkatkan Hasil Belajar Fisika Melalui Pembelajaran Dengan Pendekatan Open Ended Problem Pada Siswa Kelas VIIIC SMP Muhammadiyah 5 Mariso Makassar Tahun 2013-2014. Jurnal Pendidikan Fisika Volume 2 Nomor 1 ISSN: 2302-8939, 63-68.

Hayat, Muhammad Syaipul, Sri Anggraeni dan Sri Redjeki. (2011). Pembelajaran Berbasis Praktikum pada Konsep Invertebrata untuk Pengembangan Sikap Ilmiah Siswa. Bioma, Vol.1 ,No. 2. 141-152.

Lambertus, La Arapu, dan Tandri Patih. (2013). Penerapan Pendekatan Open-Ended untuk Meningkatkan Kemampuan Berpikir Kreatif Matematik Siswa SMP. Jurnal Pendidikan Matematika Volume 4 Nomor 1, 73-82.Fiki

Maitree Inprasitha. (2006). Open-Ended Approach and Teacher Education. Tsukuba Journal of Educational Study in Mathematics. Vol.25, 169-177.

Nenden Faridah, Isrok'atun dan Ani Nur Aeni. (2016). Pendekatan Open-Ended untuk Meningkatkan Kemampuan Berpikir Kreatif Matematis dan Kepercayaan Diri Siswa. Jurnal Pena IImiah: Vol. 1, No. 1. 10611070.

Ninomiya Hiro and Pusri Panpiti. (2015). The Study of Open-ended Approach in Mathematics Teaching Using Jigsaw Method: A Case Study of the Water Beaker Problem. 埼玉大
学紀要 教育学部, 64（2）：11- 22 .

Nurul Budiarti. (2015). Efektivitas Metode Diskusi Dengan Pendekatan Open-Ended Questions untuk Meningkatkan Hasil Belajar Fisika Siswa Kelas X SMA Muhammadiyah Kota Tegal. JRKPF UAD Vol.2 No.1 April 2015, 29-32.

Ormroad, Jeanne Ellis. (2009). Psikologi Pendidikan; Membantu Siswa Tumbuh dan Berkembang Jilid 1 Edisi 6. Jakarta: Erlangga.

Santrock, John. W. (2008). Psikologi pendidikan; Educational Psychology. Jakarta: Kencana.

Shimada, Shigeru and Becker, Jerry P. (1997). The Open-Ended Approach: A New Proposal for Teaching Mathematics. Virginia: The National Council of Teachers of Mathematics, Inc.

Sugiyono. (2012). Statistik Untuk Penelitian. Bandung: Alfabeta.

Teodoro, Vitor Duarte. (2002). Modellus: Learning Physics with Mathematical Modelling. 